\title{
STEAP4, a gene associated with insulin sensitivity, is regulated by several adipokines in human adipocytes
}

\author{
XIAOHUI CHEN ${ }^{1 *}$, CHUN ZHU ${ }^{1 *}$, CHENBO JI $^{1}$, YAPING ZHAO ${ }^{1}$, CHUNMEI ZHANG $^{1}$, \\ FUKUN CHEN $^{2}$, CHUNLIN GAO $^{1}$, JINGAI ZHU ${ }^{1}$, LINGMEI QIAN ${ }^{2}$ and XIRONG GUO ${ }^{1}$ \\ ${ }^{1}$ Department of Pediatrics, Nanjing Maternal and Child Health Hospital of Nanjing Medical University, Nanjing 210004; \\ ${ }^{2}$ Department of Cardiology, The First Affiliated Hospital of Nanjing Medical University, Nanjing 210029, P.R. China
}

Received August 26, 2009; Accepted October 19, 2009

DOI: $10.3892 /$ ijmm_00000353

\begin{abstract}
We previously identified a six-transmembrane epithelial antigen of the prostate (STEAP) 4 as a novel plasma membrane protein that is downregulated in obese patients and may play a significant role in the development of human obesity. This study was designed to identify the biological characteristics of the STEAP4 gene in human adipocytes. On the basis of oil red $\mathrm{O}$ staining and the expression profiles of specific markers, we demonstrated that overexpression of STEAP4 did not affect adipogenesis. 2-Deoxy-D-[ $\left.{ }^{3} \mathrm{H}\right]$-glucose uptake tests showed that STEAP4 promoted insulin-stimulated glucose uptake in mature human adipocytes. Further data from quantitative real-time RT-PCR and Western blotting revealed that the adipokines tumor necrosis factor $\alpha(\mathrm{TNF} \alpha)$, interleukin-6 (IL-6), and leptin, which have been implicated in insulin sensitivity regulation, regulate the expression of STEAP4. Our results demonstrate that STEAP4 does not influence human adipocyte differentiation, but it participates in regulating the insulin sensitivity of human adipocytes.
\end{abstract}

\section{Introduction}

Obesity is a complex, chronic disease and has now become a global epidemic (1). Particularly alarming is the equally marked increase in obesity among children. Obesity is associated with an array of health problems, including insulin resistance, type 2 diabetes, fatty liver disease, atherosclerosis, and some cancers.

Correspondence to: Dr Xirong Guo, Department of Pediatrics, Nanjing Maternal and Child Health Hospital of Nanjing Medical University, No. 123 Tianfei Road, Nanjing 210004, P.R. China

E-mail: xrguo@njmu.edu.cn

Dr Lingmei Qian, Department of Cardiology, The First Affiliated Hospital of Nanjing Medical University, No. 300 Guangzhou Road, Nanjing 210029, P.R. China

E-mail: lmqian@njmu.edu.cn

*Contributed equally

Key words: STEAP4, adipocyte, insulin sensitivity, tumor necrosis factor $\alpha$, interleukin-6, leptin
This cluster of pathologies has also started to emerge in children at young ages and poses a serious threat to their health $(2,3)$. Thus, exploring the pathology of obesity and obesity-related complications has become an important issue for researchers.

STEAP4, a novel obesity-related gene, was identified in our laboratory by suppression subtractive hybridization of the omental adipose tissue in obese patients and normal-weight controls (4). Previous studies have shown that STEAP4 protein is abundantly expressed in human omental adipose tissue, its expression is significantly downregulated in obese patients, and it is mainly located at the plasma membrane of adipocytes (5). These data suggest that STEAP4 plays a significant role in the development of human obesity. However, the other biological functions of this gene in human adipocytes are still unknown. Studies on the mouse homolog of STEAP4, a sixtransmembrane protein of prostate (STAMP) 2, which shares $90 \%$ amino acid identity with human STEAP4, have demonstrated that this protein is associated with adipocyte differentiation and lipid droplet accumulation (6). Recently, Wellen et al identified STAMP2 as a critical modulator of inflammation and nutrition, and also as an important protein in insulin resistance, thereby suggesting a range of functions for STEAP4 in humans (7).

In this study, we initially examined the effect of STEAP4 on cell differentiation and glucose uptake in vitro by establishing a stable preadipocyte cell line. We found that STEAP4 did not influence human adipocyte differentiation, but that it increases the insulin sensitivity of mature adipocytes. Tumor necrosis factor $\alpha(\mathrm{TNF} \alpha)$, interleukin-6 (IL-6), and leptin are important adipokines that have been implicated in insulin sensitivity regulation. We therefore examined the effect of these three adipokines on STEAP4 synthesis in vitro. We accordingly demonstrated that each of these adipokines potently regulates STEAP4 expression in fat cells. Thus, we speculate that, in human adipocytes, the STEAP4 gene is partially involved in the regulation of insulin sensitivity mediated by certain adipokines.

\section{Materials and methods}

Cell culture and treatment. Human preadipocytes (Sciencell Research Laboratories, San Diego, CA, USA) were maintained in Dulbecco's modified Eagle's medium (DMEM; Gibco, Carlsbad, CA, USA) containing 10\% fetal bovine serum (FBS; 
Table I. The sequences of oligonucleotide primers used in this study.

\begin{tabular}{|c|c|c|}
\hline Gene name & Product size & Reverse and forward primers $\left(5^{\prime}-3^{\prime}\right)$ \\
\hline \multirow[t]{3}{*}{ STEAP4 } & 169 bp & F: 5'-AACTGTACCGAGGCACAAAATAC-3' \\
\hline & & R: 5'GTTAAGTTTCCC AATCTCCATCGTA-3' \\
\hline & & Probe: 5'-(FAM)-CAGACTGGCTTGACCACTGGATGCTT-(TAMRA)-3' \\
\hline \multirow[t]{3}{*}{$18 S$} & 129 bp & F: 5'-CGGGTCGGGAGTGGGTAAT-3' \\
\hline & & R: 5'-AGTCGCCGTGCCTACCAT-3' \\
\hline & & Probe: 5'-(FAM)-CGCCTGCTGCCTTCCTTGGAGTG-(TAMRA)-3' \\
\hline \multirow[t]{2}{*}{$P P A R \gamma$} & 204 bp & F: 5'-CGAAGACATTCCATTCACAAGA-3' \\
\hline & & R: 5'-GCTTTATCTCCACAGACACGA-3' \\
\hline \multirow[t]{2}{*}{$L P L$} & 173 bp & F: 5'-CGCTCCATTCATCTCTTCATC-3' \\
\hline & & R: 5'-TTGCTGCTTCTTTTGGCTCT-3' \\
\hline \multirow[t]{2}{*}{$C / E B P \alpha$} & 172 bp & F: 5'-AGGTTTCCTGCCTCCTTCC-3' \\
\hline & & R: 5'-AGCCCCAAGTCCCTATGTTT-3' \\
\hline \multirow[t]{2}{*}{$\beta$-actin } & 234 bp & F: 5'-GGACTTCGAGCAAGAGATGG-3' \\
\hline & & F: 5'-AGCACTGTGTTGGCGTACAG-3' \\
\hline
\end{tabular}

Gibco), $100 \mathrm{U} / \mathrm{ml}$ penicillin, and $50 \mu \mathrm{g} / \mathrm{ml}$ streptomycin at $37^{\circ} \mathrm{C}$ in $5 \% \mathrm{CO}_{2}$. In order to induce differentiation, confluent human preadipocytes (day 0 ) were subsequently cultured in serum-free DMEM containing $50 \mathrm{nM}$ insulin, $100 \mathrm{nM}$ dexamethasone, $0.5 \mathrm{mM}$ 3-isobutyl-1-methylxanthine, and $100 \mu \mathrm{M}$ rosiglitazone. The medium was changed every 2 days for the first 4 days. Thereafter, the medium was replaced by serum-free DMEM containing $50 \mathrm{nM}$ insulin, and this was changed every 2 days until lipid droplets had accumulated (days 14-17). Fat accumulation was assessed by staining formalin-fixed cells with oil red $\mathrm{O}$.

On days 14-17 after the induction of differentiation, when $>75 \%$ of the cells had the morphological and biochemical properties of adipocytes, cells were used for experiments. After treatment with $10 \mathrm{ng} / \mathrm{ml} \mathrm{TNF} \alpha, 30 \mathrm{ng} / \mathrm{ml} \mathrm{IL-6,} \mathrm{or}$ $100 \mathrm{ng} / \mathrm{ml}$ leptin for different periods of time $(6,12$, or $24 \mathrm{~h})$, the adipocytes were collected and prepared for further study.

Oil red $O$ staining. Human adipocytes were cultured in 12-well plates and induced to become mature adipocytes. For oil red $\mathrm{O}$ staining, the culture medium was removed, and cells were washed twice with phosphate-buffered saline (PBS). Cells were then fixed with $4 \%$ formalin/PBS for $30 \mathrm{~min}$ at room temperature. After fixation, cells were washed with PBS again and stained with $0.6 \%(\mathrm{w} / \mathrm{v})$ filtered oil red $\mathrm{O}$ solution (60\% isopropanol, $40 \%$ water) for $60 \mathrm{~min}$ at room temperature. After washing three times, cells were observed using an optical microscope and photographed.

Establishment of a stable preadipocyte line overexpressing STEAP4. The coding sequence of STEAP4 was subcloned into the HindIII and EcoRI sites of a pcDNA3.1Myc/His (B) vector using the oligonucleotides 5'-GCGGCGAAACTTCC CTCTA-3' (sense) and 5'-GGGACCTGCACTGATTCTTC-3' (antisense) to generate a plasmid expressing the STEAP4-6xHis fusion protein. Expression vectors carrying the STEAP4 coding sequence, or empty vectors, were transfected into human preadipocytes and $48 \mathrm{~h}$ later neomycin (G418 Roche) selection (800 ng/ml) began. After 2 weeks, individual colonies were isolated and propagated, and the expression of the STEAP4$6 \times$ His fusion protein was confirmed by Western blotting using an anti-6xHis antibody. Colonies expressing the highest levels of STEAP4 were selected for further studies.

Quantitative real-time RT-PCR. Total RNA was extracted using Trizol reagent (Invitrogen, Carlsbad, CA, USA) from adipocytes and quantified spectrophotometrically at $260 \mathrm{~nm}$. cDNA was synthesized from $1 \mu \mathrm{g}$ of total RNA using an AMV Reverse Transcriptase Kit (Promega A3500; Promega, Madison, WI, USA). Real-time RT-PCR (TaqMan fluorescence method or SYBR Green method) was performed in an Applied Biosystems 7300 Sequence Detection System (ABI 7300 SDS; Foster City, CA, USA) following the manufacturer's protocols. Briefly, samples were incubated at $95^{\circ} \mathrm{C}$ for $10 \mathrm{~min}$ for initial denaturation, and then subjected to $40 \mathrm{PCR}$ cycles. Each PCR cycle consisted of $95^{\circ} \mathrm{C}$ for $15 \mathrm{sec}$ and $60^{\circ} \mathrm{C}$ for $1 \mathrm{~min}$. $18 \mathrm{~S}$ or $\mathrm{B}$-actin was used as a reference to obtain the relative fold change for target samples using the comparative CT method, the formula for which is $2^{\text {[CT(reference gene)-CT(target gene)]. }}$ The sequences of the primers used are shown in Table I.

Western blot analysis. STEAP4 protein expression was analyzed by Western blotting. After incubation with or without adipokines, mature adipocytes were directly transferred to tubes containing lysis buffer $(50 \mathrm{mmol} / 1$ Tris- $\mathrm{HCl}, 1 \%$ TritonX-100, 0.2\% sodium deoxycholate, $0.2 \%$ SDS, and $1 \mathrm{mmol} / \mathrm{l}$ EDTA at $\mathrm{pH}$ 7.4) and vortexed briefly. The lysate supernatant was collected after centrifugation at 15,200 x g for $15 \mathrm{~min}$ at $4^{\circ} \mathrm{C}$. Protein concentration determinations using a protein assay reagent kit, and Western blotting using a polyclonal rabbit anti-STEAP4 antibody and a monoclonal rabbit anti-ß-actin antibody (Proteinch Group, Inc., China), were performed as described previously (5).

Glucose uptake. 2-Deoxy-D-[ $\left.{ }^{3} \mathrm{H}\right]$-glucose (CIC, Beijing, China) uptake was assayed as described previously (8). Briefly, stably transfected cells were cultured and induced to become mature adipocytes in 6-well plates. After becoming 
A

$$
\text { STEAP4 }
$$

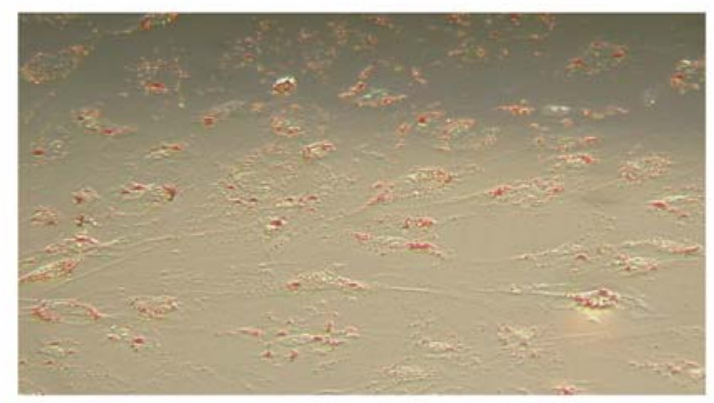

Day4

\section{Day8}

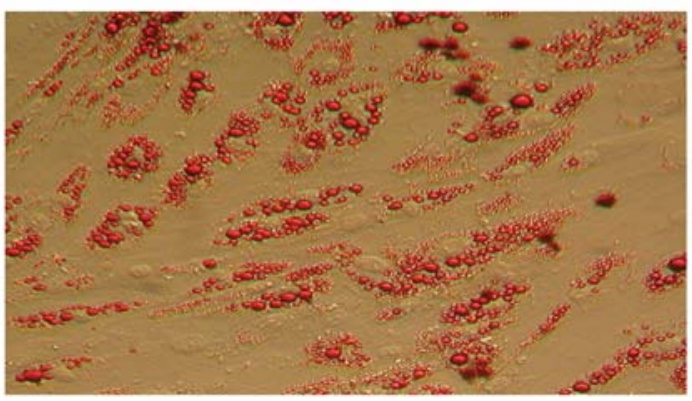

\section{Day17}

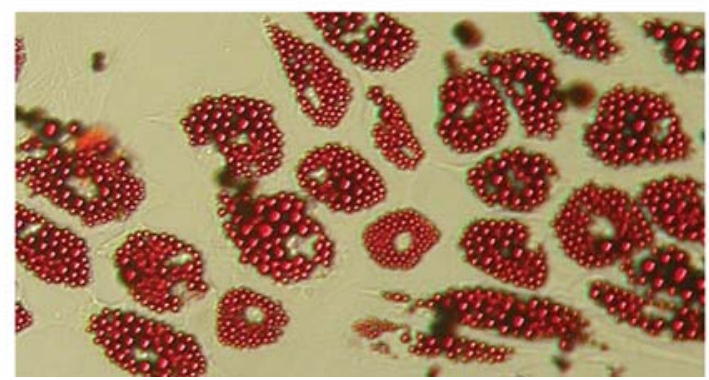

pcDNA3.1
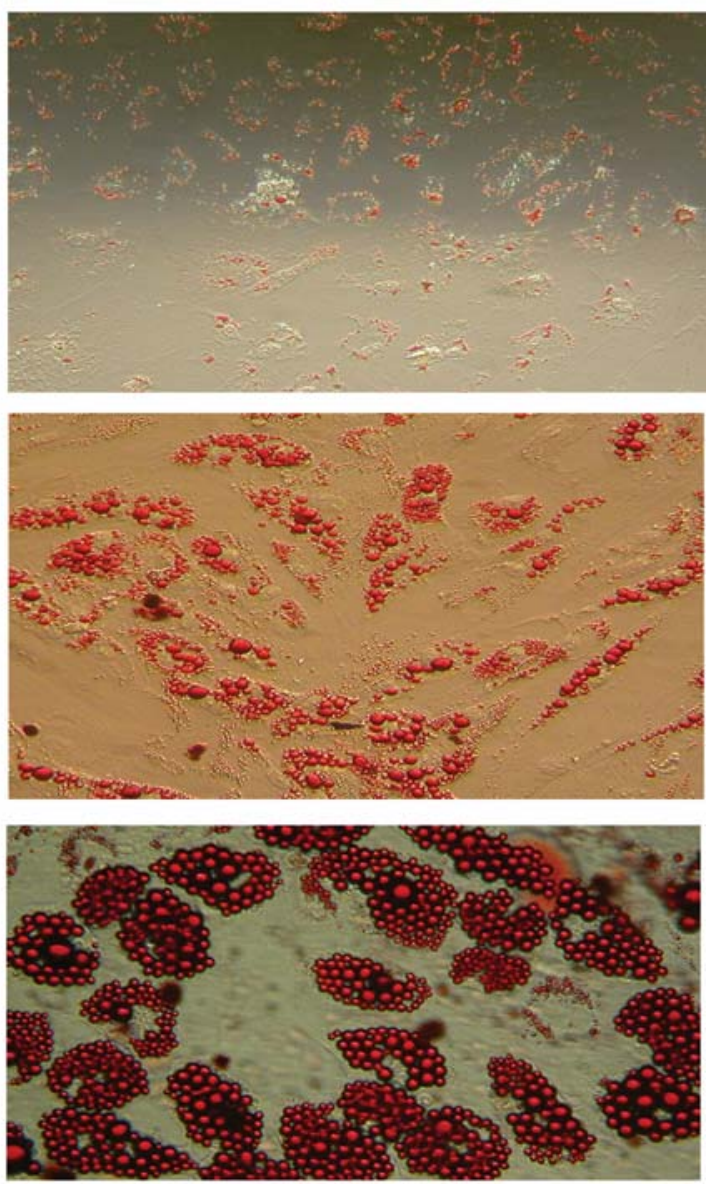

B
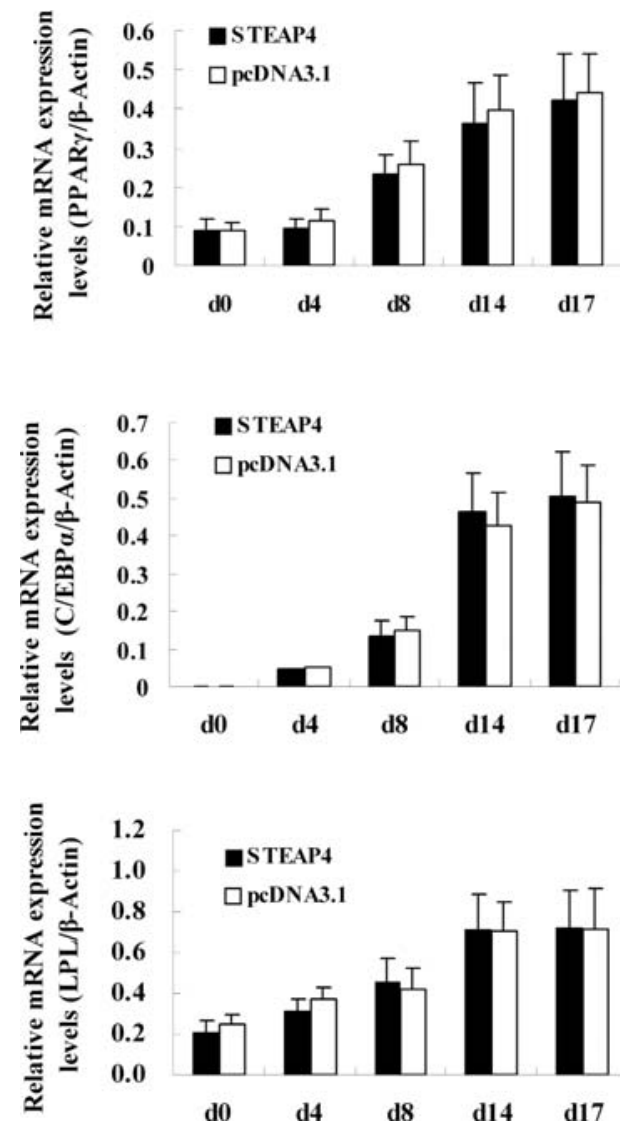

Figure 1. Effect of STEAP4 on cell differentiation. (A) Preadipocytes were transfected with pcDNA3.1Myc/HisB-STEAP4 or empty vector and induced to become mature adipocytes in vitro over 17 days. On days 4,8 , and 17, cells were fixed and stained with oil red $\mathrm{O}$ to detect the accumulation of lipid. (B) Expression of adipocyte-specific molecular markers was analyzed by quantitative real-time RT-PCR (SYBR Green method) and normalized to the $B$-actin expression at various time points during the induction of differentiation (D0, 4, 8, 14, and 17). No difference in the expression levels of these markers was found between cells with or without exogenous expression of STEAP4 $(\mathrm{P}>0.05)$. Results represent the mean \pm SD of six experiments.

fully mature, the cells were cultured in SFM medium, and then incubated with or without insulin $(100 \mathrm{nmol} / \mathrm{l})$ at $37^{\circ} \mathrm{C}$ for $30 \mathrm{~min}$. Labeled 2-deoxy-D-[ $\left.{ }^{3} \mathrm{H}\right]$-glucose was added to a final concentration of $2 \mu \mathrm{Ci} / \mathrm{ml}$. After $10 \mathrm{~min}$ at $37^{\circ} \mathrm{C}$, the reaction was terminated by washing three times with ice-cold PBS supplemented with $10 \mathrm{mmol} / \mathrm{l} \mathrm{D}$-glucose. Cells were solubilized by the addition of $200 \mu \mathrm{l}$ of $1 \mathrm{~mol} / \mathrm{l} \mathrm{NaOH}$ to each well, and aliquots of the cell lysate were transferred to scintillation vials for radioactivity counting. The remainder was used for a protein assay.

Statistical analysis. The data are presented as the means \pm SD. Data were analyzed by one-way ANOVA or Student's t-test using the SPSS 15.0 statistical package. A P-value of $<0.05$ was considered statistically significant. 


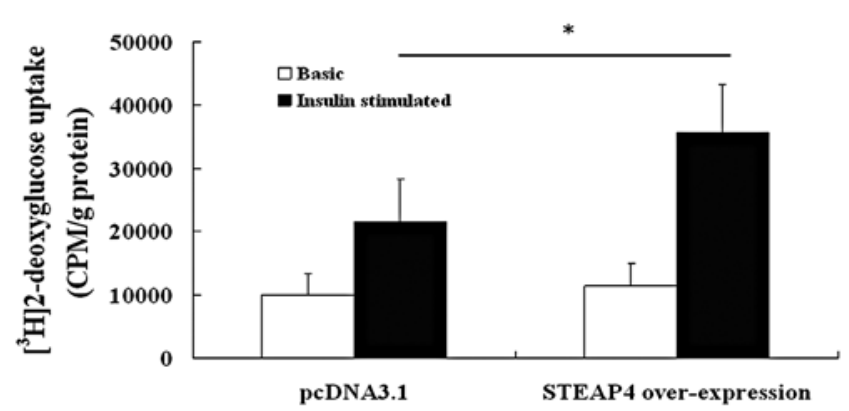

Figure 2. Effect of STEAP4 on glucose uptake. Human preadipocytes transfected with STEAP4 or the empty vector (pcDNA3.1Myc/His B) were induced to become mature adipocytes. After serum starvation, the mature adipocytes were incubated with (black columns) or without (white columns) $100 \mathrm{nmol} / 1$ insulin for $30 \mathrm{~min}$, followed by measurement of the 2-deoxy-D$\left[{ }^{3} \mathrm{H}\right]$-glucose uptake. Values represent the means \pm SD from three independent experiments. ${ }^{*} \mathrm{P}<0.05$ vs. insulin-stimulated control.

\section{Results}

Effects of STEAP4 on cell differentiation. In order to assess whether STEAP4 affects the differentiation of preadipocytes, we established a preadipocyte line stably overexpressing STEAP4 and assayed the ability of these cells to differentiate into adpocytes. As a control, preadipocytes were transfected with pcDNA 3.1/His. We found that overexpressing STEAP4 in human preadipocytes did not change the fat accumulation or cell size (Fig. 1A). In a further study, the expression of adipocyte-specific molecular markers was detected during the differentiation of adipocytes. The adipocyte-specific molecular markers included PPAR $\gamma$, LPL, and CCAAT enhancer-binding protein $\alpha(\mathrm{C} / \mathrm{EBP} \alpha)$, the expressions of which were upregulated during human preadipocyte differentiation. Results from real-time qRT-PCR showed that there was no difference in the mRNA expression of these marker genes between STEAP4overexpressing cells and controls at the same time points (days $0,4,8,14$, and 17) (Fig. 1B).

Effects of STEAP4 on basal and insulin-stimulated glucose uptake in human adipocytes. A 2-deoxy-D-glucose uptake assay was used to examine whether STEAP4 affects the glucose uptake of mature adipocytes. As shown in Fig. 2, in STEAP4overexpressing cells, basal glucose uptake was similar to that observed in the controls. However, after insulin stimulation, a significant difference was found between the two groups. In the STEAP4-overexpressing cells, insulin-stimulated glucose uptake was $\sim 75 \%$ higher than that in the controls.

\section{Adipokine regulation of STEAP4 expression in human adipocytes}

Effect of TNFa on the expression of STEAP4. The effects of $10 \mathrm{ng} / \mathrm{ml} \mathrm{TNF} \alpha$ on the expressions of STEAP4 mRNA and protein in cultured human adipocytes were assessed using real-time qRT-PCR (TaqMan fluorescence method) and Western blotting, respectively. After reaching full maturity, adipocytes were cultured in the presence or absence of $10 \mathrm{ng} / \mathrm{ml}$ TNFa. Expression of STEAP4 mRNA was found to be significantly elevated only $6 \mathrm{~h}$ after initiating TNF $\alpha$ stimulation $(\mathrm{P}<0.05)$ (Fig. 3A). This upregulation effect was time-dependent and became maximal at $24 \mathrm{~h}$, at which point the expression

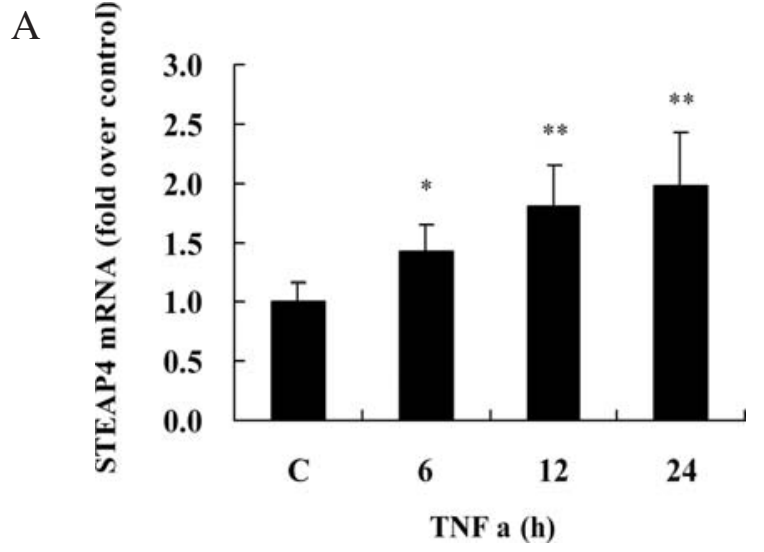

B
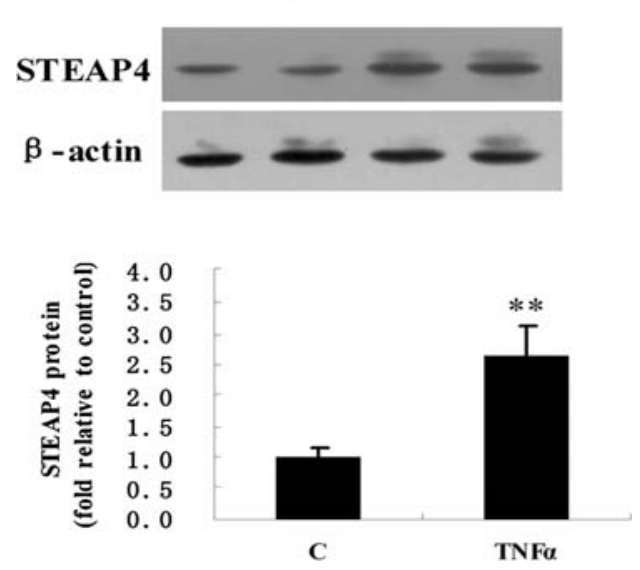

Figure 3. Effects of TNF $\alpha$ on the expression of STEAP4 mRNA and protein in human adipocytes. (A) Fully differentiated human adipocytes were treated with $10 \mathrm{ng} / \mathrm{ml} \mathrm{TNF} \alpha$ for 6,12 , or $24 \mathrm{~h}$, or without TNF $\alpha$ (control). STEAP4 mRNA levels were analyzed by quantitative real-time RT-PCR and normalized to $18 \mathrm{~S}$ levels. (B) STEAP4 protein levels were analyzed by Western blotting and normalized to $\beta$-actin levels, after treatment with or without $10 \mathrm{ng} / \mathrm{ml} \mathrm{TNF \alpha}$ for $24 \mathrm{~h}$. Results represent the mean $\pm \mathrm{SD}$. of six experiments. ${ }^{*} \mathrm{P}<0.05$, ${ }^{* *} \mathrm{P}<0.01$ vs. control (c, untreated cells).

of STEAP4 mRNA was 2.0-fold greater than that of the control $(\mathrm{P}<0.01)$. STEAP4 protein expression in mature adipocytes also increased in response to $10 \mathrm{ng} / \mathrm{ml} \mathrm{TNF} \alpha$ treatment for $24 \mathrm{~h}$ (Fig. 3B).

Effect of IL-6 on the expression of STEAP4. After treatment with $30 \mathrm{ng} / \mathrm{ml}$ IL-6 for 6,12 , and $24 \mathrm{~h}$, the STEAP4 mRNA levels in mature adipocytes were all upregulated, and the strongest upregulation effects appeared at $6 \mathrm{~h}$, being 1.8 -fold greater than that of the control $(\mathrm{P}<0.05)$. Thereafter, the levels of STEAP4 mRNA expression remained elevated for up to $24 \mathrm{~h}$. However, the upregulating effect tended to decrease with a further lengthening of the time course (Fig. 4A). The expression of STEAP4 protein exhibited a corresponding increase after treatment with $30 \mathrm{ng} / \mathrm{ml} \mathrm{IL-6}$ for $24 \mathrm{~h}(\mathrm{P}<0.01)$ (Fig. 4B).

The effect of leptin on STEAP4 expression. Treatment with $100 \mathrm{ng} / \mathrm{ml}$ leptin had a significant inhibitory effect on STEAP4 expression. Incubating mature human adipocytes with $100 \mathrm{ng} / \mathrm{ml}$ leptin for $24 \mathrm{~h}$ reduced expression of STEAP4 mRNA by 64\% $(\mathrm{P}<0.05)$ (Fig. 5A). The expression of STEAP4 protein was reduced correspondingly by $45 \%(\mathrm{P}<0.05)$ (Fig. 5B). The inhibitory effect of leptin on STEAP4 mRNA expression was generally time-dependent. 


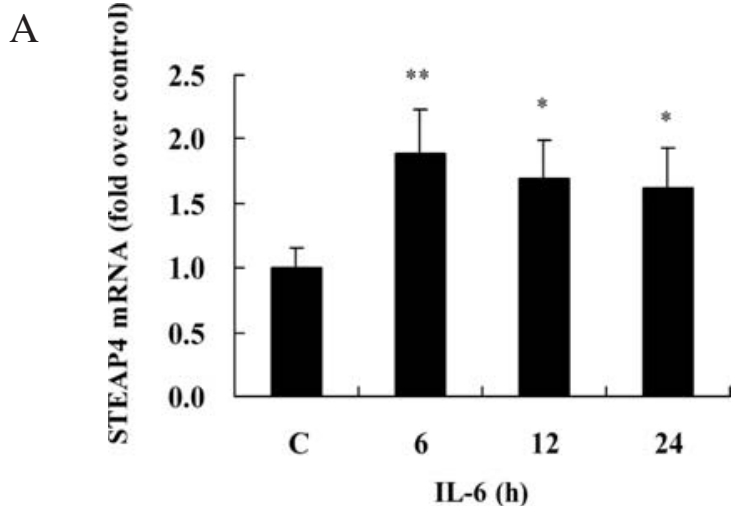

B
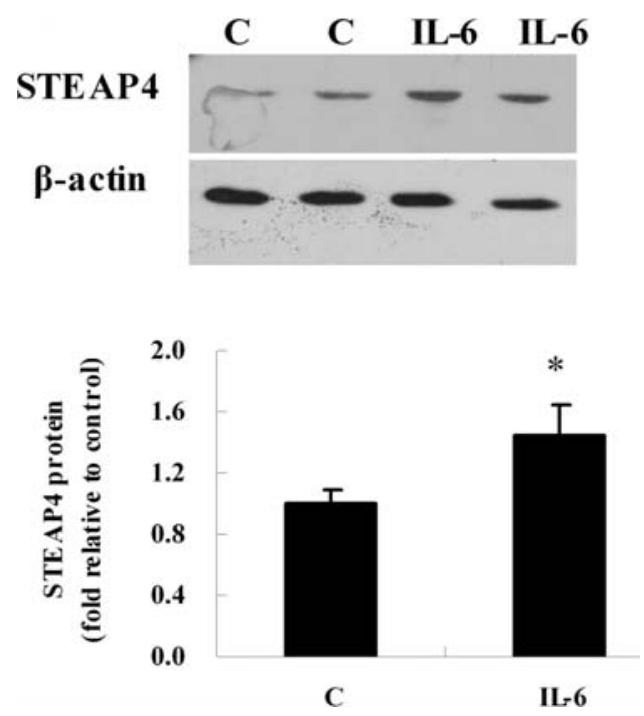

Figure 4. Effects of IL-6 on the expression of STEAP4 mRNA and protein in human adipocytes. (A) Fully differentiated human adipocytes were treated with $30 \mathrm{ng} / \mathrm{ml} \mathrm{IL-6}$ for 6,12 , or $24 \mathrm{~h}$, or without IL-6 (control), STEAP4 mRNA levels were analyzed by quantitative real-time RT-PCR and normalized to $18 \mathrm{~S}$ levels. (B) STEAP4 protein levels were analyzed by Western blotting and normalized to $\beta$-actin levels, after treatment with or without $30 \mathrm{ng} / \mathrm{ml} \mathrm{IL-6}$ for $24 \mathrm{~h}$. Results represent the mean $\pm \mathrm{SD}$ of six experiments. ${ }^{*} \mathrm{P}<0.05,{ }^{* *} \mathrm{P}<0.01$ vs. control (c, untreated cells).

\section{Discussion}

Obesity is a multifactorial disease that results from the interactions between susceptibility genes and environmental factors. Obesity is considered as a major risk factor for insulin resistance, type 2 diabetes, and cardiovascular disease. Understanding the function of obesity-related genes is therefore important for exploring the pathology of the development of obesity and obesity-related complications.

Studies on STAMP2, the mouse STEAP4 homolog $(6,7)$, have shown that this gene plays an important role in the coordinated regulation of nutrient and inflammatory responses, and that it is associated with the sensitivity to insulin in mice. In a previous study, we demonstrated that the human STEAP4 gene is highly expressed in omental adipose tissue, and that it also participates in the development of obesity (5). However, the other biological functions of human STEAP4 remain unknown.

In the present study, by establishing a stably transfected preadipocyte line overexpressing STEAP4, we found that STEAP4 did not affect the differentiation of preadipocytes, as shown by oil red $\mathrm{O}$ staining and the expression of adipocyte-

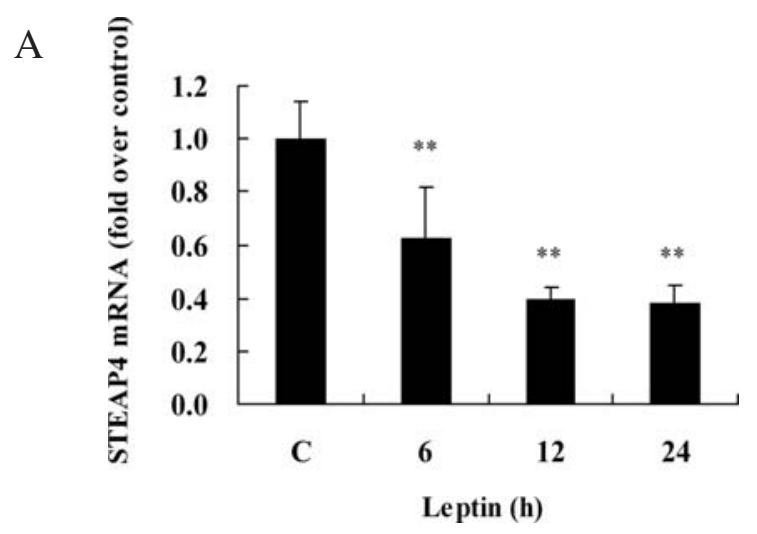

B
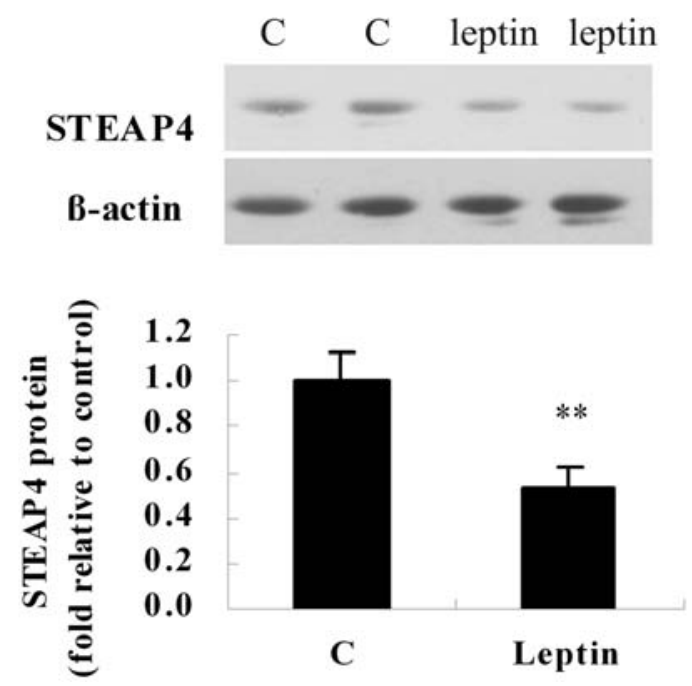

Figure 5. Effects of leptin on the expression of STEAP4 mRNA and protein in human adipocytes. (A) Mature human adipocytes were treated with $100 \mathrm{ng} / \mathrm{ml}$ leptin for 6, 12, or $24 \mathrm{~h}$, or without leptin (control). STEAP4 mRNA levels were analyzed by quantitative real-time RT-PCR and normalized to $18 \mathrm{~S}$ levels. (B) STEAP4 protein levels were analyzed by Western blotting and normalized to $\beta$-actin levels, after treatment with or without $100 \mathrm{ng} / \mathrm{ml}$ leptin for $24 \mathrm{~h}$. Results represent the mean $\pm \mathrm{SD}$ of six experiments. ${ }^{* *} \mathrm{P}<0.01$ compared with control (c, untreated cells).

specific molecular markers. Furthermore, the results from the 2-Deoxy-D- $\left[{ }^{3} \mathrm{H}\right]$-glucose uptake assay indicates that STEAP4 increases the insulin sensitivity of mature human adipocytes by promoting insulin-stimulated glucose uptake. These results thus indicate that STEAP4 plays a role in the insulin sensitivity of adipocytes. These findings are consistent with those of Wellen et al (7), who showed that STAMP2 $2^{-/}$mice exhibited insulin resistance compared with the WT. Our previous data revealed that STEAP4 is downregulated in obesity; however, whether the obesity-related insulin resistance is a consequence of the downexpression of STEAP4 requires further work.

Since the mechanism of STEAP4 action in insulin sensitivity is unknown, it would be useful to further characterize the regulation of this gene by insulin sensitivity modulating factors. $\mathrm{TNF} \alpha$ has been characterized as a key adipokine in obesity and inflammation-related insulin resistance (9-10). In the current study, we demonstrated that TNF $\alpha$ treatment led to a significant induction of STEAP4 expression at both the mRNA and protein levels. Furthermore, this unregulated effect of TNF $\alpha$ tended to be enhanced with a lengthening of the time course. Regarding the relationship between STEAP4, insulin resistance, 
and TNF $\alpha$, our results appear somewhat contradictory, in that STEAP4 was induced by TNF $\alpha$ but has the opposite reaction to TNF $\alpha$ in the regulation of insulin sensitivity. Nevertheless, our results are consistent with the study of Moldes et al, who showed that the mouse protein STAMP2 (which shares 90\% identity with human STEAP4) is induced by TNF $\alpha$, and was formerly named Tumor necrosis factor- $\alpha$ Induced AdiposeRelated Protein (TIARP) (6). We therefore consider it likely that the upregulation of STEAP4 offers protection against $\mathrm{TNF} \alpha$-induced insulin resistance. In addition, the induction of STEAP4 by TNF $\alpha$ might also be partially due to other biological functions of TNF $\alpha$ in adipocytes, such as dedifferentiation, lipolysis, and lipogenesis $(9,11)$. Further work is required to assess these possibilities.

IL-6 is another important adipocytokine since $~ 35 \%$ of systemic IL-6 originates from subcutaneous fat cells in vivo (12). Accumulating evidence indicates the beneficial role of IL-6 in insulin sensitivity (13-16). In humans, IL-6 infusion increases subcutaneous adipose tissue glucose uptake (14). Furthermore, IL-6 knockout mice develop late-onset obesity and impaired glucose tolerance (15). There are several mechanisms that could potentially explain the positive effect on insulin sensitivity mediated by IL-6, including the stimulation of fatty acid oxidation and increasing glucose uptake by activation of AMPK in both skeletal muscle and adipose tissue (16). However, the signaling pathways and molecular mechanisms mediating these effects of IL-6 are far from clear. Our study indicates that IL-6 treatment significantly increases STEAP4 expression in human adipocytes, with a maximal effect occurring at $6 \mathrm{~h}$. On the basis of this observation, we suspect that the upregulation of STEAP4 expression induced by short-term IL- 6 treatment leads to enhanced insulin sensitivity. However, other studies have demonstrated an impairment of insulin sensitivity by IL-6 (17). Considering these conflicting results, further investigations regarding the changes in insulin sensitivity during the course of regulation are warranted.

Leptin is an adipocyte-secreted hormone that is coded by the $o b$ gene (18). By directly interacting with the hypothalamus, leptin plays an important role in energy balance regulation in vivo (18). Recently, leptin was also proved to be an important molecule in obesity-related insulin resistance. Most obese subjects are presented with hyper-leptin levels in circulation and leptin resistance (19). In vitro, hyper-leptin levels directly induce insulin resistance in the liver and adipose tissue $(20,21)$. In the current study, we found that leptin exerted a significant inhibitory effect on STEAP4 expression in human adipocytes. The present findings suggest that the leptin-induced downregulation of STEAP4 expression contributes to insulin resistance.

It seems apparent from our results that STEAP4 increase the sensitivity of insulin in adipocytes and that its expression is greatly affected by a variety of adipokines that are involved in insulin sensitivity regulation. In addition, a predictive structural analysis of the STEAP4 protein suggests a potential function of STEAP4 in electron transport and energy metabolism $(6,22)$ and other members of the STEAP4 family have been characterized as metalloreductases capable of facilitating the cellular uptake of iron, which is required in both glucose and lipid metabolism (23). All these findings support our deduction that STEAP4 participates in regulating the insulin sensitivity of human adipocytes and is involved in obesityrelated IR. Our study has preliminarily characterized the factors regulating STEAP4 and has revealed different regulation models for different adipokines. TNF $\alpha$ and IL-6 both induce STEAP4 expression, whereas leptin treatment results in decreased expression. The mechanisms underlying these different regulations are still unknown. Future studies addressing the biochemical and functional properties of STEAP4 will provide insights into its role in adipocyte biology.

\section{Acknowledgements}

This work was supported by grants from the National Natural Science Foundation of China (Grant Number: 30772364), the Foundation of Ministry of Education, China (Grant Number: 20070312001), the Natural Science Foundation of Jiangsu Province, China (Grant Number: BK2007230), and Nanjing Medical University (Grant Number: 07NMUZ024, 08NMUM066).

\section{References}

1. Haslam DW and James WP: Obesity. Lancet 366: 1197-1209, 2005.

2. Reilly JJ: Obesity in childhood and adolescence: evidence based clinical and public health perspectives. Postgrad Med J 82: 429-437, 2006.

3. Flodmark CE, Lissau I and Pietrobelli A: Child and adolescent obesity: why we need to fight! Acta Paediatr (Suppl) 94: 4-7, 2005.

4. Qiu J, Ni YH, Gong HX, et al: Identification of differentially expressed genes in omental adipose tissues of obese patients by suppression subtractive hybridization. Biochem Biophys Res Commun 352: 469-478, 2007.

5. Zhang CM, Chi X, Wang B, et al: Downregulation of STEAP4, a highly-expressed TNF-alpha-inducible gene in adipose tissue, is associated with obesity in humans. Acta Pharmacol Sin 29: 587-592, 2008.

6. Moldes M, Lasnier F, Gauthereau X, Klein C, Pairault J and Feve B: Tumor necrosis factor-alpha-induced adipose-related protein (TIARP), a cell-surface protein that is highly induced by tumor necrosis factor-alpha and adipose conversion. J Biol Chem 276: 33938-33946, 2001.

7. Wellen KE, Fucho R, Gregor MF, et al: Coordinated regulation of nutrient and inflammatory responses by STAMP2 is essential for metabolic homeostasis. Cell 129: 537-548, 2007.

8. Ceddia RB, Somwar R, Maida A, Fanq X, Bikopouls G and Sweeney G: Globular adiponectin increases GLUT4 translocation and glucose uptake but reduces glycogen synthesis in rat skeletal muscle cells. Diabetoloqia 48:132-139, 2005.

9. Moller DE: Potential role of TNF-alpha in the pathogenesis of insulin resistance and type 2 diabetes. Trends Endocrinol Metab 11: $212-217,2000$

10. Stephens JM, Lee J and Pilch PF: Tumor necrosis factor-alphainduced insulin resistance in 3T3-L1 adipocytes is accompanied by a loss of insulin receptor substrate-1 and GLUT4 expression without a loss of insulin receptor-mediated signal transduction. J Biol Chem 272: 971-976, 1997.

11. Gasic S, Tian B and Green A: Tumor necrosis factor alpha stimulates lipolysis in adipocytes by decreasing Gi protein concentrations. J Biol Chem 274: 6770-6775, 1999.

12. Mohamed-Ali V, Goodrick S, Rawesh A, Katz DR, Miles JM, Yudkin JS, Klein S and Coppack SW: Subcutaneous adipose tissue releases interleukin-6, but not tumor necrosis factor-alpha, in vivo. J Clin Endocrinol Metab 82: 4196-4200, 1997.

13. Glund S, Deshmukh A, Long YC, et al: Interleukin-6 directly increases glucose metabolism in resting human skeletal muscle. Diabetes 56: 1630-1637, 2007.

14. Lyngso D, Simonsen L and Bulow J: Metabolic effects of interleukin-6 in human splanchnic and adipose tissue. J Physiol 543: 379-386, 2002. 
15. Wallenius V, Wallenius K, Ahrén B, et al: Interleukin-6-deficient mice develop mature-onset obesity. Nat Med 8: 75-79, 2002.

16. Carey AL, Steinberg GR, Macaulay SL, et al: IL-6 increases insulin stimulated glucose disposal in humans and glucose uptake and fatty acid oxidation in vitro via AMPK. Diabetes 55: 2688-2697, 2006.

17. Rotter V, Nagaev I and Smith U: Interleukin-6 (IL-6) induces insulin resistance in 3T3-L1 adipocytes and is, like IL-8 and tumor necrosis factor-alpha, overexpressed in human fat cells from insulin-resistant subjects. J Biol Chem 278: 45777-45784, 2003.

18. Zhang Y, Proenca R, Maffei M, Barone M, Leopold L and Friedman JM: Positional cloning of the mouse obesegene and its human homologue. Nature 372: 425-432, 1994

19. Van Dielen FM, van 't Veer C, Buurman WA and Greve JW: Leptin and soluble leptin receptor levels in obese and weightlosing individuals. J Clin Endocrinol Metab 87: 1708-16, 2002 .
20. Girard J: Is leptin the link between obesity and insulin resistance? Diabetes Metab 23:16-24, 1997

21. Müller G, Ertl J, Gerl M and Preibisch G: Leptin impairs metabolic actions of insulin in isolated rat adipocytes. J Biol Chem 272: 10585-10593, 1997.

22. Korkmaz CG, Korkmaz KS, Kurys P, et al: Molecular cloning and characterization of STAMP2, an androgen-regulated six transmembrane protein that is overexpressed in prostate cancer. Oncogene 24: 4934-45, 2005.

23. Ohgami RS, Campagna DR, McDonald A and Fleming MD: The Steap proteins are metalloreductases. Blood 108: 1388-1394, 2006. 